\title{
Field and laboratory experiments on interference between Hydrobia totteni and Ilyanassa obsoleta (Gastropoda) and its possible relation to seasonal shifts in vertical mudflat zonation
}

\author{
Jeffrey S. Levinton, S. Stewart \& T. H. Dewitt \\ Department of Ecology and Evolution", State University of New York at Stony Brook, Stony Brook, New York 11794, USA \\ and \\ Laboratoire Arago, F-66650 Banyuls-Sur-Mer, France
}

\begin{abstract}
Laboratory and field experiments demonstrate that the mud snail Ilyanassa obsoleta strongly interferes with the smaller-sized Hydrobia totteni. Filter cages permitting free movement of $H$. totteni, but not $I$. obsoleta, demonstrate significant $H$. totteni emigration in the presence of $I$. obsoleta. In summer and early fall, when $I$. obsoleta is found in the low intertidal. H. totteni is confined to the upper intertidal and in the lowest intertidal where $I$. obsoleta is absent. In winter, when I. obsoleta migrates below mean low water, $H$. totteni abundance shifts downward. The interference effect observed with field and laboratory cages may underlie the seasonal $H$. totteni migration pattern.
\end{abstract}

\section{INTRODUCTION}

In European tidal and non-tidal mudflats the genus Hydrobia is usually given the common name of 'mud snail' (e.g. Fenchel 1975, Hylleberg 1975, Fenchel \& Kofoed 1976). This attests to the ubiquity and great densities of principally Hydrobia ulvae (e.g. Newell 1964, Fenchel 1975). However, on the eastern coast of North America, the term 'mud snail' is applied to the ubiquitous nassarid Ilyanassa obsoleta. This species is now a conspicuous resident of mudflats, but once lived in a broader variety of habitats before the arrival of the periwinkle Littorina littorea (Brenchley \& Carlton 1983 and references therein). Its diet can be varied, but probably is mainly confined to deposit feeding (e.g. Curtis \& Hurd 1981, Connor \& Edgar 1982). The genus Hydrobia has a similar main diet (Newell 1965, Fenchel et al. 1975, Lopez \& Kofoed 1980) and is occasionally as abundant as in the European Atlantic and North Sea region (e.g. Sanders et al. 1962, Wells 1978), but its habitat distribution in American soft bottoms is clearly reduced. In the region of Stony Brook, New York,

\footnotetext{
- Address for correspondence
}

broad sand flats of low slope - usually containing Hydrobia in Danish waters - only contain Ilyanassa obsoleta (J. Levinton pers. obs.). Coexistence of Hydrobia and Ilyanassa obsoleta, however, does occur on mudflats, though an overall pattern of non-overlapping zones is present (e.g. Levinton \& Bianchi 1981). The large mobile Ilyanassa obsoleta (2 to $4.5 \mathrm{~cm}$ adult length) might be expected to affect negatively the smaller Hydrobia totteni $(3 \mathrm{~mm}$ adult length: Levinton \& Bianchi 1981). Are there any negative interactions?

The possible role of interference between Ilyanassa obsoleta and Hydrobia totteni is also important from the point of view of resource utilization and limitation. Hydrobia populations are commonly at densities where resource limitation by food availability is likely (Fenchel \& Kofoed 1976, Levinton \& Lopez 1977. Levinton \& Bianchi 1981). I. obsoleta is efficient at grazing and digestion of diatoms (Pace et al. 1979, Connor \& Edgar 1982), the principal source of food for Hydrobia (Fenchel \& Kofoed 1976, Levinton \& Bianchi 1981), and seems to be far more effective at reducing microalgal standing stocks than $H$. totteni (Bianchi \& Levinton 1981). However, significant as it may seem, this effect may be minor relative to interference effects. 


\section{MATERIALS AND METHODS}

We used laboratory and field experiments, and field surveys to examine the interaction between Ilyanassa obsoleta and Hydrobia totteni. Field collections came from mudflats in a small Spartina alterniflora salt marsh, Flax Pond, located near the Flax Pond Marine Laboratory (Marine Sciences Research Center, State University of New York). Previous work (e.g. Levinton \& Bianchi 1981) has demonstrated the long-term persistence of $H$. totteni at fairly constant densities.

Laboratory experiment. Sediment collected from the ' $3 \mathrm{~m}$ ' level of field transects, to be discussed below, was passed through a $1 \mathrm{~mm}$ sieve and placed in rectangular plastic pans $\left(240 \mathrm{~cm}^{2}\right)$ to a depth of $1 \mathrm{~cm}$; the latter were inserted into a recirculating seawater tank under lights and maintained at ca. $18^{\circ} \mathrm{C}$ (Levinton \& Bianchi 1981). Plastic screening surrounded the outside of the pans to prevent escape. A baffle screen of ca. $4 \mathrm{~mm}$ mesh separated the pan into 2 equal parts. Then, 120 adult Hydrobia totteni were placed on each side (density of 1 snail $\mathrm{cm}^{-2}$ ). After $48 \mathrm{~h}, 2$ Ilyanassa obsoleta (corresponding to a density of 167 snails $\mathrm{m}^{-2}$ ) were added to one side of experimental pans, but controls were maintained to correct for a possible bias with respect to water movement within the aquarium. The I. obsoleta density used was twice that observed in a field site to be discussed below, but well within the range of common densities (e.g. Pace et al. 1979, Connor et al. 1982). After $1 \mathrm{wk}$, the sediment on either side of the baffle was passed through a $1 \mathrm{~mm}$ sieve and the H. totteni were counted (Fig. 1).

Field experiments and surveys. In the field in July, circular filter cages $-40 \mathrm{~cm}$ diameter (ca. $0.1260 \mathrm{~m}^{2}$ ) and ca. $12 \mathrm{~cm}$ high - were constructed of aluminum mesh, ca. 6 to $8 \mathrm{~mm}$ in mesh size and implanted in the

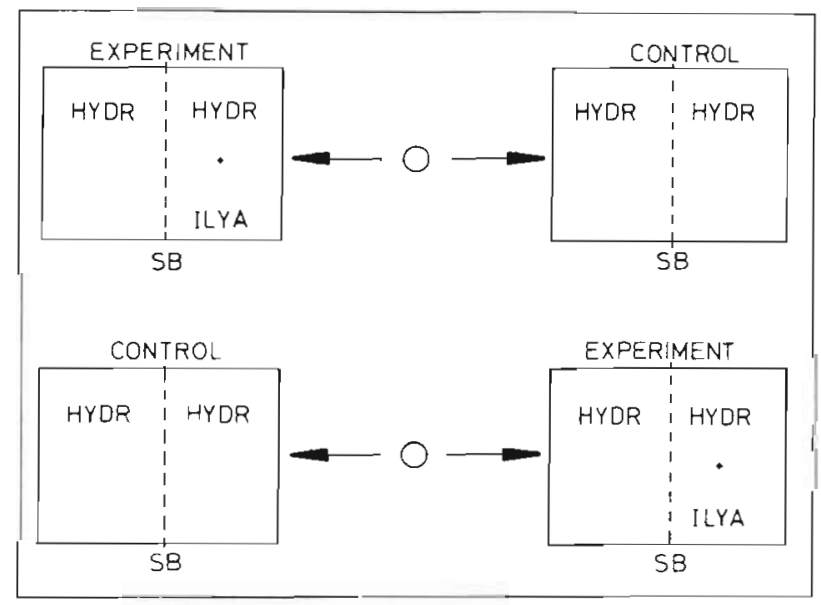

SB = SCREEN BAFFLE HYDR = HYDROB $\mid \mathrm{A} \quad$ ILYA $=$ ILYANASSA

Fig. 1. Scheme of laboratory experiment designed to examine the effect of Ilyanassa obsoleta on Hydrobia totteni sediment. In 3 sites, ca. 2 m apart on a line at the same tide level, 3 treatments were established: 0, 10, and 20 Ilyanassa obsoleta cage ${ }^{-1}$, corresponding to 0,83 , and 167 snails $\mathrm{m}^{-2}$, respectively. Background density of $I$. obsoleta was estimated by counting the number of snails in rings the same size as the cage, laid in a line across the 3 sites. Five circular cores, $2.5 \mathrm{~cm}$ in diameter by $10 \mathrm{~cm}$ deep, were taken at the middle site and sieved through a $0.5 \mathrm{~mm}$ mesh to estimate the Hydrobia totteni background density. After 1 mo, 5 cores were taken in each replicate cage and all $H$. totteni were counted. I. obsoleta experimental densities were adjusted periodically, and the degree of loss or gain was small. This experiment, conducted in 1982, was repeated in summer 1983, using a higher $I$. obsoleta density of 34 individuals cage ${ }^{-1}$ (283 snails $\mathrm{m}^{-2}$ ).

In September 1981, a series of sites on 2 mudflats adjacent to the Flax Pond laboratory were selected for variation in Ilyanassa obsoleta densities. At each of these sites 10 cores were taken and sieved for counts of Hydrobia totteni, and 25 quadrats $(25 \times 25 \mathrm{~cm})$ were surveyed for $I$. obsoleta. We sampled a transect for $I$. obsoleta and $H$. totteni in a tidal flat immediately northeast of the Flax Pond laboratory (Levinton \& Bianchi 1981) 4 times from September 1982 to July 1983. Grain size analysis was done by wet-sieving blended sediment collected at sites along the transect. Tidal heights were measured using a surveyor's level. The flat had a regular drop of $1 \mathrm{~cm} \mathrm{~m}^{-1}$ transect. At each sampling site 10 cores were taken for estimates of $H$. totteni, and 5 quadrats, $0.5 \times 0.5 \mathrm{~m}$, were used to count I. obsoleta.

\section{RESULTS}

\section{Initial field survey}

Fig. 2 shows the relation between Ilyanassa obsoleta and Hydrobia totteni density over 9 sites purposefully chosen over a range of $I$. obsoleta densities. A strong negative relationship between the 2 species was found. Below $I$. obsoleta densites of ca. 15 to 20 snails $\mathrm{m}^{-2}, H$. totteni densities increase to those typical of persistent adult populations at Flax Pond (Levinton \& Bianchi 1981).

\section{Laboratory experiment}

Fig. 3 shows the number of Hydrobia totteni on either side of the baffles, with and without Ilyanassa obsoleta, after $1 \mathrm{wk}$. In the experimental trays, $H$. totteni density was strongly depressed in the presence of I. obsoleta (Contingency Analysis of 4 replicate experiments: $G=11.09, p<.01 ; G=42.49, p<.001$; $\mathrm{G}=5.14, \mathrm{p}<.05 ; \mathrm{G}=5.39, \mathrm{p}<.05)$. The effect of $I$. 


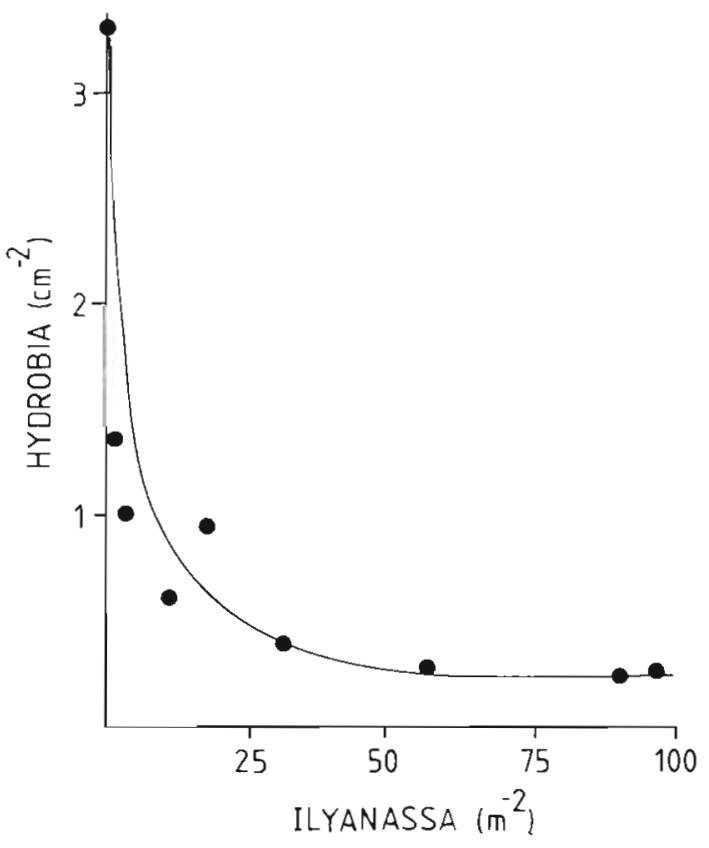

Fig. 2. Relation between field densities of Hydrobia totteni and Ilyanassa obsoleta in a series of sites selected for variation in $I$. obsoleta density. Each point is a mean for 10 cores for $H$. totteni and 25 quadrats for I. obsoleta

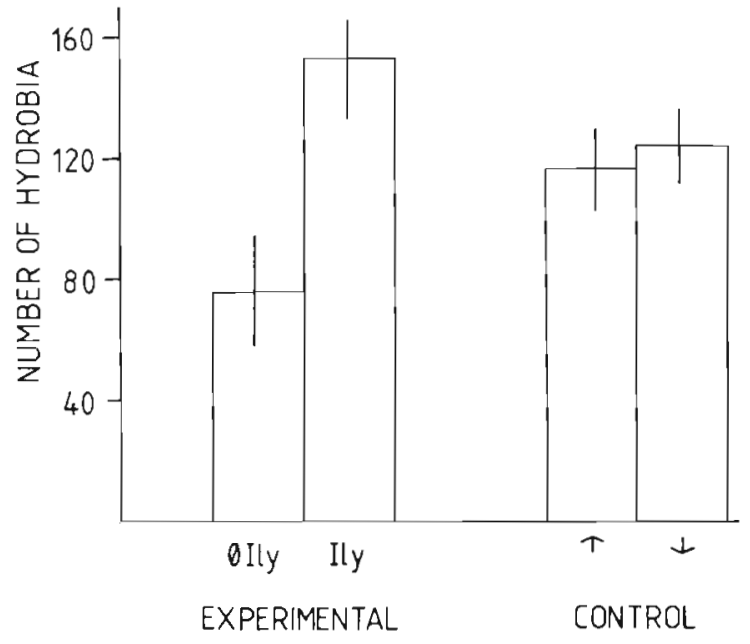

Fig. 3. Number of Hydrobia totteni, with and without $I l y$ anassa obsoleta, versus a control where the side of the dish was upstream or downstream (indicated by arrows) of the water source in the aquarium

obsoleta is an underestimate, as $H$. totteni also exhibits intraspecific density-dependent emigration (Levinton 1979, J. Levinton unpubl.). Therefore some of the increase in density in the no- $I$. obsoleta sides of the trays would result in a pressure for reverse emigration. The controls (Fig. 3) demonstrated no difference in density, irrespective of orientation to the water flow within the aquarium.

\section{Field experiment}

Fig. 4 illustrates the abundance in cages of Hydrobia totteni as a function of experimental site and Ilyanassa obsoleta density. A 2-way analysis of variance shows no significant variation in density among sites, but significant $(F=22.62$, d.f. $=2,36, p<.001$ ) variation among $I$. obsoleta density treatments. As Fig. 4 demonstrates, $H$. totteni density decreases strongly with increasing $I$. obsoleta density. Background $I$. obsoleta density was estimated as $13 \pm 3.12(\mathrm{SE}: \mathrm{N}=25$ ) snails $\mathrm{m}^{-2}$, while background $H$. totteni density was $19.3 \pm$ 2.94 (SE: $N=6$ ) snails core ${ }^{-1}$. It should be noted that the background $H$. totteni density is substantially less than the densities found in the no-I. obsoleta cages. This indicates that these cages attracted $H$. totteni, possibly as the result of the $I$. obsoleta present in the external milieu. Over the course of the month, $H$. totteni densities probably steadily built up in the noI. obsoleta cage treatments. In the repeat experiment the next year, a similar negative effect of $I$. obsoleta on $H$. totteni was found. After a $10 \mathrm{~d}$ experiment, $H$. totteni density with $I$. obsoleta was $1.38 \pm 0.539$ (SE: $\mathrm{N}=16$ ) snails core $\mathrm{e}^{-1}$. Density without $I$ obsoleta was $7.31 \pm 1.356$ (SE: $\mathrm{N}=16$ ) snails core ${ }^{-1}$. H. totteni density in absence of $I$. obsoleta is significantly greater (t-test, $\mathrm{t}=4.07, \mathrm{p}<.001$ ). Background $H$. totteni density was $4.49 \pm 2.008$ ( $\mathrm{SE}: \mathrm{N}=5$ ), which cannot be distinguished statistically from the no-I. obsoleta treatment.

\section{Seasonal transect study}

Fig. 5 shows the seasonal distribution at dead low tide of Ilyanassa obsoleta and Hydrobia totteni as a function of distance seaward from the edge of the mudflat (0 m mark). In September, a distinct inverse relation is apparent. $H$. totteni was most abundant at the highest tide level, decreased progressively with decreasing tidal height, and was rarest in a zone where I. obsoleta occurred at densities over 80 snails $\mathrm{m}^{-2}$. This pattern was also found in a previous survey, in September of 1980 (Levinton \& Bianchi 1981). Of note is the increase in $H$. totteni below the point where $I$. obsoleta density decreased dramatically. This pattern changed dramatically in fall and in winter, when the $I$. obsoleta population migrated below mean low water. During these times, the peak of $H$. totteni abundance shifted downward, where I. obsoleta had been formerly abundant. In May and June, I. obsoleta returned to the intertidal zone. The survey done the following July shows the same pattern seen in the previous September, including the increase of $H$. totteni density at the tidal level below which $I$. obsoleta starts to decline in abundance. 


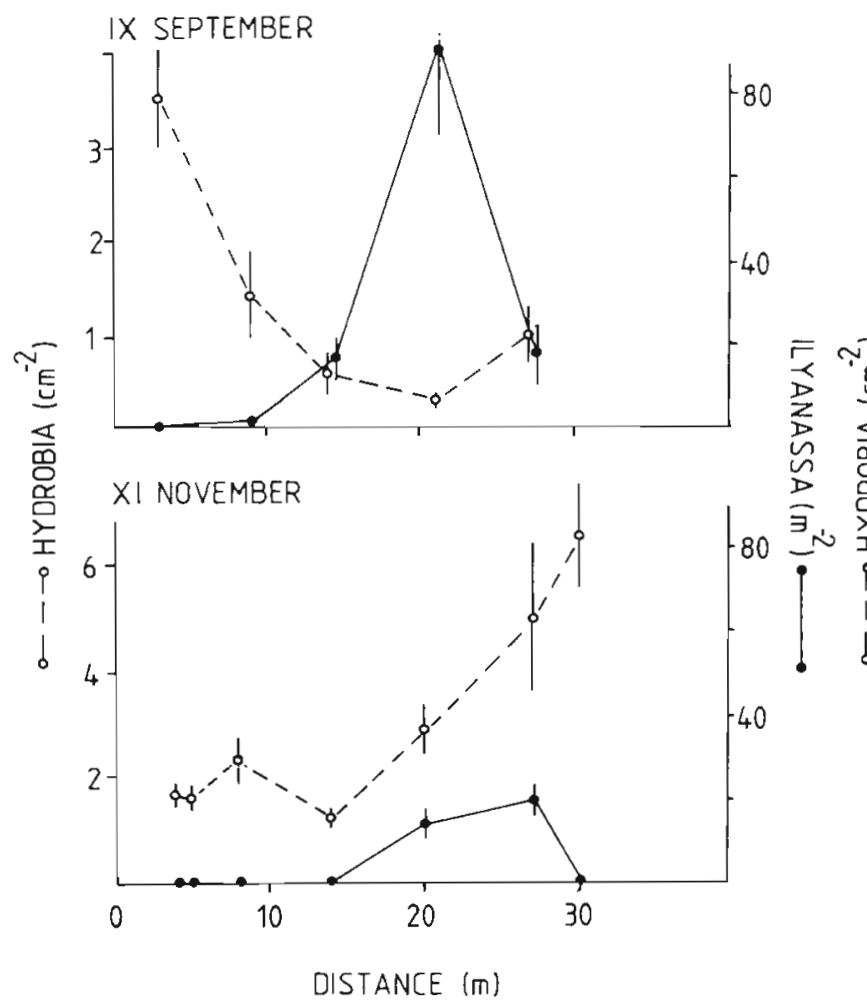

II FEBRUARY

Fig. 4. Abundance of Hydrobia totteni after 1 mo in field cages with varying abundances of Ilyanassa obsoleta

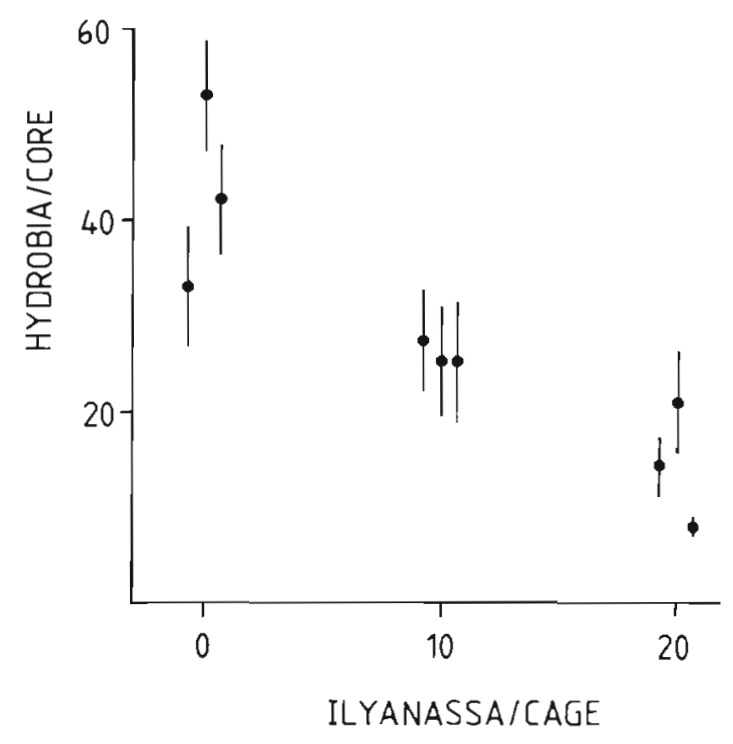

Fig. 5. Seasonal variation (number of month and month indicated) of Ilyanassa obsoleta and Hydrobia totteni as a function of tidal height $10 \mathrm{~m}$ transect distance represents edge of mudflat with drop of $1 \mathrm{~cm} \mathrm{~m}^{-1}$ of transect)

Our qualitative observations indicate that in summer the Ilyanassa obsoleta population on the flat exists in a dense band and does not move much below the $35 \mathrm{~m}$ transect mark. Its negative effects on other organisms are liable to be greatest at this level. As the tide rises we were able to see some movement, but the band does not seem to keep its integrity, and high-tide surveys usually fail to detect more than occasional $I$. obsoleta at any given site higher than the locus of the low-tide band. We have no evidence for tidal movement of Hydrobia totteni, but this is unlikely as we have rarely observed any floating individuals in Flax Pond.

\section{DISCUSSION}

Laboratory and field experiments demonstrate a strong interference effect of Ilyanassa obsoleta on $\mathrm{Hy}$ drobia totteni. The effect is probably not qualitatively different from the effect of intraspecific interference within dense $H$. totteni populations (Levinton 1979). At high density, $H$. totteni are 'set in motion' and do not stop to feed as frequently. This results in densitydependent emigration (Levinton 1979). An experiment demonstrated this intraspecific effect by keeping $H$. totteni at $0.5,2,4$, and 8 snails $\mathrm{cm}^{-2}$ and then placing them in glass dishes at the same density. Snails that had experienced densities of 2 individuals $\mathrm{cm}^{-2}$ moved to the top of the dish and floated at a significantly higher rate than those kept at 0.5 individuals $\mathrm{cm}^{-2}$ (Kruskal Wallace test, $\mathrm{H}^{\prime}=9.7, \mathrm{p}<.01$ ), a probable reflection of increased motility due to increase of snailsnail encounters. At densities of 4 to 8 snails $\mathrm{cm}^{-2}$ a depression of crawling and floating was noted (though 
movement was still greater than at 0.5 snails $\mathrm{cm}^{-2}$ ) as a result of previously depressed movement at high density (Levinton 1979).

In this context, an Ilyanassa obsoleta individual can be viewed as having the effect of several Hydrobia totteni individuals when encountering an $H$. totteni. In the laboratory, I. obsoleta turns over the sediment to a much greater degree than $H$. totteni. Similar plowing can be seen regularly in field populations. The results reported above suggest that the interference effect of $I$. obsoleta upon $H$. totteni may be of far greater importance than the depression of microalgal standing stocks.

It is difficult to classify symmetrically this interaction as 'competition'. In regard to Ilyanassa obsoleta it is not clear that Hydrobia totteni exerts much of an effect other than reducing algal standing stocks to a degree. But with regard to $H$. totteni, $I$. obsoleta probably strongly inhibits feeding and encourages local emigration. Its movement effectively monopolizes space that would otherwise be available to $H$. totteni and therefore exerts a sort of priority effect. Were this effect not easily conceived in terms of an $H$. totteni intraspecific density-dependent effect, we might have thought of it as biological disturbance, much as a periwinkle bulldozes off barnacle cypris larvae from a hard substrate (Dayton 1971).

Due to its relatively poor resistance to desiccation, Ilyanassa obsoleta is confined to the lower part of the mudflat. This leaves a refuge for Hydrobia totteni in the upper intertidal zone. In the Flax Pond mudflat, however, $I$. obsoleta also has a lower extent; $H$. obsoleta increases in abundance below this zone. This observation would weaken the possible alternative hypothesis that $H$. totteni prefers the upper intertidal, or a correlated environmental parameter such as sediment type. Furthermore, $H$. totteni does not migrate below low water in winter, and often survives under ice with low mortality (J. Levinton, unpubl.). Though speculative, there is therefore likely to be a direct relationship between our experimental results on interference and the conspicuously coordinated seasonal vertical movements of $H$. totteni in response to $I$. obsoleta seasonal migrations.

Seasonal survey and experimental results resemble those of Race (1982) on the effects of newly introduced Ilyanassa obsoleta on a native mudsnail in San Francisco Bay. Brenchley \& Carlton (1983) also noted an interference effect of Littorina littorea on I. obsoleta, after the spread of the former into New England waters. L. littorea grazes on the shells of $I$. obsoleta and thus strongly disturbs the latter. But on the northeast coast of North America, both 'mudsnail' species are presumably native. The continuous negative interaction is thus not the result of recent departure from an equilibrium condition, due to a sudden introduction of an exotic competitor or biological disturbance agent. The system here is dynamic and changing continuously in response to migrations and probably changes of abundance. In March 1984, a strong winter storm at Flax Pond was followed by a late spring recruitment of juvenile 1. obsoleta, the only one that we have observed in our surveys since 1977. A decrease in Hydrobia totteni followed the storm and we expect that a newly established dense I. obsoleta population will make the decrease permanent.

This study underscores the dangers inherent in drawing conclusions on the effects of environmental parameters with benthic macrofauna by means of correlation analysis. Hydrobia ulvae abundance in British waters has been shown to correlate with fine particles in the sediment and this has been related to food abundance (Newell 1964). Fig. 6 shows the strong

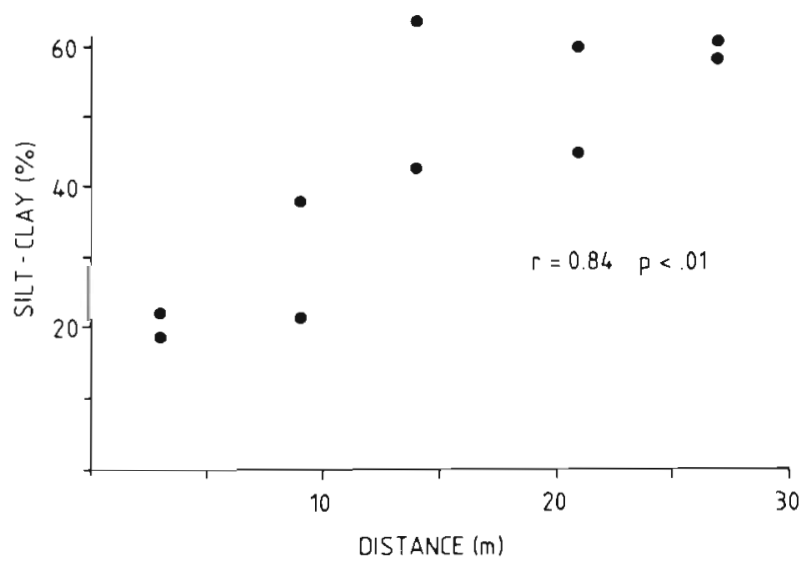

Fig. 6. Silt-clay content of sediment as a function of transect distance (as in Fig. 4)

negative correlation between silt-clay content (sediment fraction less than $63 \mu \mathrm{m}$ in diameter) and tidal height. One might be readily confused in trying to induce causality from this correlation. In summer, one would search for factors related to the positive aspects of coarser sediments; in winter, fine sediment would be thought to be better for the snails. The entire seasonal pattern combined with the field experiments show that the sediment is largely irrelevant to the peak abundance of $H$. obsoleta. This problem emphasizes the need for an experimental approach in the study of deposit feeding systems.

Acknowledgements. We are very grateful to Marleen Jones and William Gala who did the laboratory experiment, and to Peter Petraitis who did the density-floating experiment. We also thank Jeffrey Baumgartner, David Berg, Paul Klerks and Yuki Yamamoto for help in the field and in the laboratory.

Supported by a US National Science Foundation Research Grant (Biological Oceanography). Contribution number 516 from the Graduate studies in Ecology and Evolution. State University of New York at Stony Brook. 


\section{LITERATURE CITED}

Bianchi, T. S., Levinton, J. S. (1981). Nutrition and food limitation of deposit-feeders. II. Differential effects of Hydrobia totteni and Ilyanassa obsoleta on the microbial community. J. mar. Res. 39: 547-556

Brenchley, G. A., Carlton, J. T (1983). Competitive displacement of native mud snails by introduced periwinkles in the New England intertidal zone. Biol. Bull. mar. biol. Lab., Woods Hole 165: 543-558

Connor, M. S., Edgar, R. K. (1982). Selective grazing by the mud snail Iyanassa obsoleta. Oecologia (Berl.) 53: 271-275

Connor, M. S., Teal, J. M., Valiela, I. (1982). The effect of feeding by mud snails. Myanassa obsoleta Say, on the structure and metabolism of a laboratory benthic algal community. J. exp. mar. Biol. Ecol. 65: 29-45

Curties, L. A., Hurd, L. E. (1981). Nutrient procurement strategy of a deposit-feeding estuarine neogastropod, $I l y$ anassa obsoleta. Estuar. coast. Shelf Sci. 13: 277-285

Dayton, P. K. (1971). Competition, disturbance and community organization: the provision and subsequent utilization of space in a rocky intertidal community. Ecol. Monogr. 41: $351-389$

Fenchel, T. (1975). Factors determining the distribution patterns of mud snails (Hydrobiidae). Oecologia 20: 1-17

Fenchel, T., Kofoed, L. H. (1976). Evidence for exploitative interspecific competition in mud snails. Oikos 27: 367-376

Fenchel, T., Kofoed, L. H., Lappalainen, A. (1975). Particle size-selection of two deposit feeders: the amphipod Corophium volutator and the prosobranch Hydrobia ulvae. Mar. Biol. 30: 119-128

Hylleberg, J. (1975). The effect of salinity and temperature on egestion in mud snails (Gastropoda: Hydrobiidae): a study on niche overlap. Oecologia 21: 279-289
Levinton, J. S. (1979). The effect of density upon depositfeeding populations: moving, feeding, and floating of Hydrobia ventrosa Montagu (Gastropoda, Prosobranchia). Oecologia (Berl.) 43: 27-39

Levinton, J. S., Bianchi, T. S. (1981). Nutrition and food limitation of deposit-feeders. I. The role of microbes in the growth of mud snails (Hydrobiidae). J. mar. Res. 39: $531-545$

Levinton, J. S., Lopez, G. R. (1977). A model of renewable resources and limitation of deposit-feeding benthic populations. Oecologia (Berl.) 31: 177-190

Lopez, G. R., Kofoed, L. H. (1980). Epipsammic browsing and deposit feeding in mud snails (Hydrobiidae). J. mar. Res. 38: $585-599$

Newell, R. C. (1964). Some factors controlling the upstream distribution of Hydrobia ulvae (Pennant) (Gastropoda, Prosobranchia). Proc. zool. Soc. Lond. 142: 85-106

Newell, R. C. (1965). The role of detritus in the nutrition of two marine deposit feeders, the prosobranch Hydrobia ulvae and the bivalve Macoma balthica. Proc. zool. Soc. Lond. 144: 25-45

Pace, M. L., Shimmel, S., Darley, W. M. (1979). The effect of grazing by a gastropod. Nassarius obsoletus, on the benthic microbial community. Estuar. coast. mar. Sci. 9: $121-134$

Race, M. S. (1982). Competitive displacement and predation between introduced and native mud snails. Oecologia 54: $337-347$

Sanders, H. L., Goudsmit, E. M., Mills, E. L., Hampson, G. E. (1962). A study of the intertidal fauna of Barnstable Harbor, Massachusetts. Limnol. Oceanogr. 7: 63-79

Wells, F. E. (1978). The relationship between environmental variables and the density of the mudsnail Hydrobia totteni in a Nova Scotia salt marsh. J. mollusc. Stud. 44: 120-129 